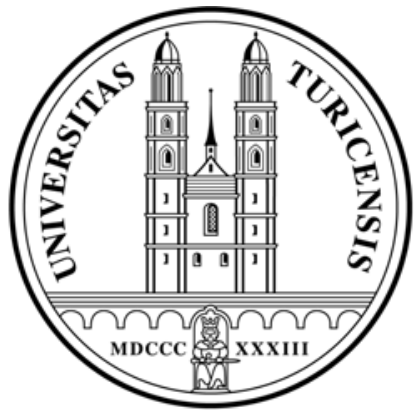

Institute for Empirical Research in Economics

University of Zurich

Working Paper Series

ISSN 1424-0459

Working Paper No. 184

Valuing Public Goods: The Life Satisfaction Approach

Bruno S. Frey, Simon Luechinger and Alois Stutzer

March 2004 


\title{
Valuing Public Goods: The Life Satisfaction Approach
}

\author{
Bruno S. Frey, Simon Luechinger and Alois Stutzer
}

University of Zurich

March 8, 2004

\begin{abstract}
This paper discusses a novel approach to elicit people's preferences for public goods, namely the life satisfaction approach. Reported subjective well-being data are used to directly evaluate utility consequences of public goods. The strengths of this approach are compared to traditional approaches and identification issues are addressed. Moreover, it is applied to estimate utility losses caused by terrorist activities in France, the UK and the Republic of Ireland. Terrorism in these countries depresses life satisfaction in a sizeable and robust way. However, the calculation of the trade-off between terrorism and income requires improved measurement of the marginal utility of income. (100 words)
\end{abstract}

JEL classification: D61, D74, H41, H56, I31

Keywords: life satisfaction approach, non-market valuation, cost-benefit analysis, subjective well-being, and terrorism

\footnotetext{
* University of Zurich, Institute for Empirical Research in Economics, Bluemlisalpstr. 10, CH-8006 Zurich, Switzerland. The first and third authors are also affiliated with CREMA - Center for Research in Economics, Management and the Arts. Phone +41163437 28, fax +41163449 07, e-mail bsfrey@iew.unizh.ch, sluechinger@iew.unizh.ch, astutzer@iew.unizh.ch. We are grateful to Ed Glaeser, Lorenz Goette, Stephan Meier and Dina Pomeranz for helpful comments and to Rosemary Brown for improving the English.
} 


\section{Valuing Public Goods: The Life Satisfaction Approach}

\section{Introduction}

How valuable are national security and law enforcement, clean air and scenic beauties or the protection of the cultural heritage to individuals? More generally, the question is how individuals value different public or publicly provided goods. It is commonplace that individuals have no incentive to disclose their true demand for non-excludable goods; it is advantageous to understate demand when it positively affects contribution requirements and to overstate demand otherwise. Therefore, some economists are very pessimistic as to whether it is possible to assess people's preferences for public goods: "[T]he very essence of the public goods problem is that there is no way these preferences can be determined" (Due and Friedlaender 1973, p. 53; emphasis added).

In contrast to this negative view, a vast literature exists, reflecting extensive research and considerable progress in valuing public goods in monetary terms. Essentially, two avenues have been pursued: revealed preference methods on the one hand and stated preference methods on the other hand. The former are based on actual behavior and utilize complementary and substitutive relationships between public and various marketed goods to infer the value attributed to public goods from market transactions in private goods. Examples are the hedonic market approach, the travel cost approach and the averting or mitigating behavior method, to name just the most prominent ones. In the case of stated preference methods, individuals are directly asked to value the public good in question; the most prevalent method is contingent valuation. Both avenues have their weaknesses. Revealed preference methods are based on stringent assumptions, crucial elements are inherently difficult to measure and non-use values cannot be captured. The hypothetical nature of contingent valuation surveys, on the other hand, may entail unreliable results and strategic behavior.

The life satisfaction approach presented in this paper constitutes a novel and potentially effective approach. It correlates the degree of public goods or public bads with individuals' reported subjective well-being and evaluates them directly in terms of life satisfaction, as well as relative to the effect of income. This approach obviates some of the major difficulties inherent in both the revealed preference and stated preference methods. As it is not based on observed behavior, the underlying assumptions are less restrictive and non-use values can - to some extent - be measured. Furthermore, individuals are not asked to value the public good directly, but to evaluate their general subjective well-being, life satisfaction or happiness. This is presumably a cognitively less demanding task, does not evoke answers considered desirable by the persons asked, and there is no reason to expect strategic behavior. 
A growing literature in economics uses data on reported subjective well-being and investigates the determinants of happiness at the individual level (e.g. socio-demographic factors, income and employment status) and at the societal level (e.g. unemployment rate, inflation, inequality and democratic institutions). Reported subjective well-being can serve as an empirically adequate and valid approximation for individual utility. Hence, it is an obvious and straightforward strategy to directly evaluate public goods in utility terms. By measuring the marginal utility of a public good or the marginal disutility of a public bad, as well as the marginal utility of income, the trade-off ratio between income and the public good can be calculated.

This paper has two major objectives. Firstly, we want to make the life satisfaction approach more widely known and discuss some conceptual issues (section 2). Secondly, we apply it to terrorism, a topic that gained notoriety in recent years and is likely to be high on the political agenda for many years to come (section 3). ${ }^{1}$ Security, or the absence of terrorism, is a fundamental public good and one of the primary justifications of the existence of the state. However, its provision competes with other public goods, and agents want to know its valuation relative to private goods and other public services. When the costs imposed on people by terrorist activities are known, the government can be expected to make better decisions on how many resources should be mustered to deal with terrorism. This holds even if the government is not viewed as a social-welfare maximizing agent, but is rather seen to act in a setting characterized by political competition. The utility losses caused by terrorist activities are estimated for France, Ireland and the United Kingdom. France is the Western European country with the highest number of recorded international terrorist incidents in the last quarter of the $20^{\text {th }}$ century. Similarly, the terrorist conflict in Northern Ireland, the socalled 'Troubles', affected not only Northern Ireland but also Great Britain and the Republic of Ireland. We are able to show that individuals living in a region prone to terrorist activities suffer considerable utility losses. The calculation of the trade-off between terrorism and income, however, requires an improved measurement of the marginal utility of income. Section 4 offers concluding remarks.

\section{The Life Satisfaction Approach to Value Public Goods}

\subsection{The Basic Concept}

Influenced by the positivistic movement in philosophy, standard economics is based on an "objectivistic" position. Individual utility is inferred from actual behavior and subjectivist experience as captured by surveys is rejected as being not objectively observable and therefore "unscientific". The axiomatic approach holds that the choices made by individuals

\footnotetext{
${ }^{1}$ For an overview and further references on the economics of terrorism, see e.g. Enders and Sandler (1995); Frey and Luechinger (2003); Sandler and Enders (2004).
} 
provide all the information required to infer the utility of outcomes. However, this position restricts the questions that can be addressed. It is, for example, not possible to discriminate between competing theories that predict the same patterns in behavior, but differ in what they put forward as people's utility level (Frey and Stutzer 2003). Moreover, conceptions about individuals' preferences or utility functions remain vague and the valuation of public goods is hampered (Arrow 1958, pp. 8-9; Schelling 1968, pp. 143-144). Revealed preference cannot be applied in all cases of interest and non-use values leave no behavioral trace. It is, therefore, no accident that non-market valuation is a field in economics where surveys have been widely used.

The recent development of happiness research in economics poses a new challenge to the objectivistic position (for surveys see Frey and Stutzer 2002a, b; Layard 2004). ${ }^{2}$ Due to extensive work by numerous psychologists spanning many decades, the measurement of utility has made great progress. The subjective approach to utility accounts for the great variety of individuals' ideas about happiness and the good life and recognizes that observed behavior is an incomplete indicator for individual well-being. Following the economic tradition of relying on the judgment of the persons directly involved, people are considered to be the best judges of the overall quality of their life. With the help of representative surveys, it is possible to get indications of individuals' evaluation of their life satisfaction. It can be captured with single-item or multi-item questions; a prominent example of the former is the Euro-Barometer Survey Series asking: "On the whole, are you very satisfied, fairly satisfied, not very satisfied, or not at all satisfied with the life you lead?" People evaluate their level of subjective well-being with regard to circumstances and comparisons to other persons, past experience and expectations of the future. Therefore, behind the score indicated by a respondent lies a cognitive assessment to what extent their overall quality of life is judged in a favorable way (Veenhoven 1993). The measures of reported subjective well-being are thus promising empirical approximations to individual utility.

Measures of reported subjective well-being passed a series of validation exercises, revealing that people reporting high subjective well-being are more often smiling during social interactions and are less likely to commit suicide. Changes in brain activity and heart rate account for substantial variance in reported negative affect. Reliability studies found that reported subjective well-being is fairly stable and sensitive to changing life circumstances (see Frey and Stutzer 2002b for references). However, in order to conduct welfare comparisons on the basis of reported subjective well-being, further conditions have to be met. Well-being must be cardinal and interpersonally comparable. Economists are likely to be skeptical about both claims. However, evidence has been accumulated that both of them may be less of a problem on a practical level than on a theoretical level (e.g. Kahneman 1999;

\footnotetext{
${ }^{2}$ The empirical study of happiness used to be the province of psychology; recent surveys are Diener et al. (1999) and Kahneman et al. (1999a).
} 
Ferrer-i-Carbonell and Frijters 2004). Happy people, for example, are rated as happy by friends and family members (e.g. Sandvik et al. 1993), as well as by spouses. Furthermore, ordinal and cardinal treatments of satisfaction scores generate quantitatively very similar results in micro-econometric happiness functions (Frey and Stutzer 2002a). Happiness research in economics has indeed come up with important and challenging findings, e.g. about the psychic costs of unemployment, the relativity in utility judgments from income or the trade-off between unemployment and inflation.

Basically, there are two different ways to analyze the determinants of life satisfaction. Firstly, an indirect utility function with income and other arguments of a representative individual can be studied. In the empirical analysis, a micro-econometric happiness function is estimated, in which an individual's utility is approximated by reported subjective well-being. Explanatory variables are his/her (household) income and a vector of socio-demographic and socioeconomic characteristics, as well as societal, economic and institutional conditions the individual is faced with. Secondly, aggregate data can be analyzed. Usually, simple crosscountry analyses are conducted, with the average happiness levels as the dependent variable, and economic, social and institutional indicators as explanatory variables.

Reported subjective well-being data can be used to assess individuals' preferences for public goods or externalities. The public good or the externality faced by an individual is included as an additional argument in the indirect utility function, or as an additional explanatory variable in the micro-econometric happiness function, respectively. Similarly, the quantity of public goods provided, or the prevalent levels of externalities in different countries, can be included in cross-country analyses with aggregate data. The estimated coefficients can be interpreted as marginal utilities of the public goods or the marginal disutilities of the public bads. Together with estimates for the marginal utility of income, the marginal rate of substitution between income and the public good can be calculated. Because the indifference curve over income and the public good is estimated directly, both relevant welfare measures, the equivalent surplus and the compensating surplus, can be computed even for inframarginal changes in the provision of the public good, without the need of auxiliary assumptions.

In the case of decreasing marginal utility of income and/or decreasing marginal utility of public good consumption, the willingness-to-pay or willingness-to-accept of different income classes and/or different base levels of the public good provision can be estimated. Furthermore, heterogeneity of preferences across income classes (or other subgroups of the population) with regard to the public good can be captured with interaction terms. Both the exact functional form of the utility curves and preference heterogeneity across predefined subgroups of the population are ultimately empirical questions that can be addressed using life satisfaction data.

The life satisfaction approach can be used to value a wide range of different public goods and bads, negative and positive externalities. Hitherto, the approach was exclusively used to value 
externalities in the environmental realm. Van Praag and Baarsma (2001) were the first authors to use life satisfaction data explicitly for the evaluation of externalities. They analyze the effect of noise nuisance in the area of the Amsterdam Airport using individual data. Because subjective well-being is influenced by perceived rather than objective noise levels, and because the former depends not only on the latter, but also on a number of intervening variables, like the presence of noise insulation and individual characteristics, the estimated compensations vary considerably for different groups of persons. Cross-country analyses are conducted by Welsch (2002) and Rehdanz and Maddison (2003). Welsch (2002) identifies a negative effect of urban air pollution (more precisely the amount of nitrogen dioxide) on average life satisfaction that translates into considerable monetary values of improved air quality. Rehdanz and Maddison (2003) investigate the relationship between happiness and climate, and calculate the necessary change in GDP per capita to hold happiness at its current levels in the face of predicted climate changes.

\subsection{Comparison with Alternative Approaches}

The life satisfaction approach has several advantages over the most prominent revealed preference methods and stated preference methods.

Stated preference methods: contingent valuation. In a contingent valuation survey, respondents are asked to value a specific public good. ${ }^{3}$ This is often an unfamiliar situation and gives rise to problems of strategic responses. Therefore, the credibility, validity and reliability of results based on contingent valuation are the subject of heated controversy in economics.

Skepticism is largely based on the empirically observed "embedding effect" (Kahneman and Knetsch 1992) that refers to several interrelated regularities in contingent valuation surveys. Firstly, in some studies, the willingness-to-pay is almost independent of the quantity of the public good provided (insensitivity to scale and scope). Further, if multiple goods are valued in one survey, the willingness-to pay for a particular public good often depends on its position in the sequence (sequencing effect). Finally, the sum of willingness-to-pay for individual changes separately exceeds the willingness-to-pay for a composite change in a group of public goods (sub-additivity effect). Critics see the "embedding effect" as evidence for the non-existence of individual preferences for the public good; individuals receive a "warm glow" from expressing support for good causes and, accordingly, the survey process creates the values it seeks to reveal (e.g. Diamond and Hausman 1994). However, meta-analyses find significant sensitivity to scale and scope (e.g. Smith and Osborne 1996) and, according to proponents, the sequencing and the sub-additivity effect can be explained in terms of substitution effects and diminishing marginal rates of substitution (e.g. Hanemann 1994;

\footnotetext{
${ }^{3}$ See Carson et al. (2003) for an elaborate and state-of-the-art contingent valuation study; they estimate individuals' willingness to pay to prevent another Exxon Valdez type oil spill.
} 
Carson et al. 2001). A number of guidelines have been developed to assure credibility, validity and reliability. The most important are the presentation of adequate information, the choice of a credible (hypothetical) payment mechanism and the use of the referendum format, the only elicitation format that is - at least under certain circumstances - incentive-compatible (Arrow et al. 1993; Portney 1994).

Nevertheless, the basic problem of the contingent valuation method remains. Due to the hypothetical nature of the questions asked and the unfamiliarity of the task, one cannot exclude that respondents fail to consider the effect of their budget constraints and substitutes. Symbolic valuation in the form of attitude expression and superficial answers are likely to be the result (Kahneman et al. 1999b). Similarly, the problem of strategic behavior can onlybe addressed to a limited extent. The life satisfaction approach is not affected by either of these problems. It does not rely on respondents' ability to consider all relevant consequences of a change in the provision of a public good. It suffices if they state their own life satisfaction with some degree of precision. This considerably reduces the "informational and computational burden" on the subjects (Di Tella et al. 2002, p. 9). Moreover, there is no reason to expect strategic behavior.

Revealed preference methods. This other group of non-market valuation techniques is based on the idea that, when choosing between different bundles of public and private goods, individuals make a trade-off, revealing something about the value they place on these goods. Under specific circumstances, this enables inferences to be made about individuals' willingness-to-pay for the public good from market transactions in the private good. In the following, the (i) hedonic market approach, (ii) the travel cost approach, (iii) the averting behavior method and their respective weaknesses are compared to the life satisfaction approach employed here.

(i) Revealed preference methods: hedonic market approach. If individuals derive utility from a local public good, they prefer to live in regions with a high provision of this good and, hence, bid up housing rents and bid down wages in these regions. The public good is a qualitative characteristic of the differentiated market good housing and of jobs; the housing and labor market thus function as markets for the public good. Wage and rent differentials serve as implicit prices and correspond, in equilibrium, to the individuals' marginal willingness-to-pay for the public good (e.g. Rosen 1974). ${ }^{4}$ Here lies a first and fundamental problem of the hedonic market approach: the approach is based on the assumption that housing and labor markets are in full equilibrium. This assumption is justified only when households have a very high degree of information, when there is a sufficiently wide variety of houses and jobs, when prices adjust rapidly, when transaction and moving costs are low, as

\footnotetext{
${ }^{4}$ Exemplary contributions are Blomquist et al. (1988) and Chay and Greenstone (2001). The former estimate compensations for intraurban and interregional differences in amenities in the labor and housing market, the latter investigate the effect of air pollution and successfully address the identification issues hedonic market studies are normally plagued with.
} 
well as when there are no market restrictions (Freeman 2003, p. 366). In contrast, the life satisfaction approach explicitly captures utility losses in the absence of market equilibria. Compensating variation in other markets, however, has to be accounted for in cross-section analyses. If they are not, the life satisfaction approach captures only the residual externality (Van Praag and Baarsma 2001, p.15-16; see also discussion in section 2.3). In this case, the life satisfaction approach and the hedonic market approach complement each other. Another drawback of the hedonic market approach is the need to account for adjustments people are likely to make in response to changes in the level of an externality, as well as reactions of the supply side of the hedonic market.

(ii) Revealed preference methods: travel cost approach. Whereas in the hedonic market approach people are assumed to relocate with regard to regional differences in public goods, the travel cost approach rests on the premise that location decisions are driven by other factors. Instead, individuals spend time and money traveling to and consuming publicly provided goods, like cultural institutions and recreational sites. ${ }^{5}$ Under certain circumstances, individuals' willingness-to-pay can be inferred from these expenditures (Clawson and Knetsch 1966; for advanced models see e.g. Freeman 2003; Parsons 2003). ${ }^{6}$ Hence, the travel cost approach, in contrast to the life satisfaction approach, is only applicable if the consumption of the publicly provided good entails costs. In addition, the shadow price of time is critical to the evaluation of the public good, but inherently difficult to observe (Randall 1994).

(iii) Revealed preference methods: defense expenditure approach. The defense expenditure approach relies on the fact that private expenditures for security measures may serve as a substitute for public security measures. Similarly, in order to mitigate adverse consequences of an exposure to a public bad, various strategies that incur expenditures are open to an individual. A decrease in this exposure or, alternatively, an increase in public security measures, leads to a decline in private defense expenditures, which in turn reflects individuals' evaluation of the public good or bad. The approach depends on the assumption of perfect substitutability between a public or a publicly provided good and private goods (see e.g. Zeckhauser and Fisher 1976). ${ }^{7}$ While a substitutive relationship is often plausible, perfect substitutes represent a special case that is unlikely to prevail in many policy areas of interest (Pommerehne 1987, p. 25). Averting behavior should also not affect utility directly, neither positively nor negatively. Moreover, the perceived cost and risk reduction capability of a particular averting behavior are of utmost importance, but hardly measurable. People's perception of the degree of substitutability between public and private goods, risk reduction

\footnotetext{
${ }^{5}$ It is a central but equivocal assumption of the travel cost approach that travel serves no other purpose than the consumption of the public good and in itself provides no utility or disutility.

${ }^{6}$ For an application of the travel cost model, see e.g. Hausman et al. (1995). They estimate utility losses due to the Exxon Valdez oil spill like Carson et al. (2003), who use contingent valuation surveys. The effect estimated with contingent valuation is more than 700 times higher than the one estimated with the travel cost approach.

${ }^{7}$ A recent contribution is e.g. Bresnahan et al. (1997).
} 
capability of averting behavior, as well as the costs and direct utility consequences thereof, all influence their reactions to the exposure to a public bad and are reflected in their utility level. The life satisfaction approach measures the utility losses caused by the public bad, as well as the defense expenditures directly, and can therefore be applied without any knowledge of people's reactions.

A problem common to all methods based on revealed preference is that consumption and relocation decisions are based on perceived rather than objective (dis-)amenity levels; in case people's perceptions and objective measures do not correspond sufficiently, the estimates may be severely biased. The same caveat applies, to some extent, to the life satisfaction approach. However, in contrast to revealed preference methods, the life satisfaction approach captures indirect effects of externalities on individuals' utility through effects on health and the like, even if there are no direct effects. For example, whereas noise nuisance affects utility directly and results in corresponding defense expenditures or relocation decisions, exposure to nuclear radiation can damage health through a process unnoticed by the people, but which nevertheless lowers life satisfaction. In this case, utility losses cannot be measured using revealed preference methods, as there is no behavioral trace. For the same reason, revealed preference methods cannot assess non-use values like the existence and bequest value. In this regard, the life satisfaction approach is superior, though it is not able to capture pure existence values (or pure public goods more generally) as discussed below. In addition, behavioral research has shown that there exists a distinction between two notions of utility: experienced utility on the one hand and decision utility on the other hand. The experienced utility of an outcome encompasses the hedonic experience of that outcome, while the decision utility is the weight an individual assigns to that outcome in a decision (Kahneman 1994). As Rabin (1998, p. 33) points out, "[t]he realization that decision and experienced utility may be systematically different cuts to the core [...] of our methods of research, requiring us to formulate ways of inferring and eliciting preferences that go beyond a method of 'revealed preference' method [...] through such methods as self reports of satisfaction." In other words, if experienced utility and decision utility systematically differ, decisions in markets for private goods do not accurately reveal people's hedonic experiences from the consumption of public goods.

\subsection{Identification of Utility Changes}

As the preceding discussion suggests, there are a number of ingenious approaches to valuing public goods. They are, however, plagued with a number of problems, which hamper or prevent their application to specific goods of interest. The life satisfaction approach obviates several of these problems; its application instead of, or complementary to, the traditional approaches therefore seems promising. In the following, we explore the requirements and discuss some identification issues of the life satisfaction approach. 
Omitted variables. The life satisfaction approach, like the revealed preference methods, is not immune to possible spurious correlations that are the result of omitted variables. If differences in self-reported life satisfaction are explained by cross-sectional differences in the public good, the estimates may be severely biased due to unobserved factors that covary with life satisfaction and the public good. For concreteness consider terrorism. Imagine that people in terrorism-prone regions report on average a lower life satisfaction than their counterparts in peaceful areas. Obviously, the regions differ from each other in various ways other than the level of terrorist activities which are likely to influence the life satisfaction of its residents.

There are two ways of addressing this problem, though it cannot be completely resolved. ${ }^{8}$ Firstly, the use of data with panel structure allows for the control of time-invariant regionspecific differences in life satisfaction, as well as area-independent temporal variations. Still, there may be time-variant regional effects that are correlated with happiness and the variable of concern, be it causal or not. Unemployment among young men and a general lack of opportunities during an economic downturn could, for example, further the recruitment in terrorist groups and simultaneously depress life satisfaction in the affected regions. Another key issue, therefore, is to control for potentially collinear variables. However, the lack of adequate indicators often limits this procedure. Government reactions to terrorist activities, like curfews and curtailing of civil liberties, are likely to entail utility losses, but are difficult to operationalize.

Compensating variation. According to the premise of the hedonic market approach, individuals (without firm-specific investments and land ownership) exposed to a public bad or negative externalities are compensated in private markets, above all in the labor and housing market. Similarly, public goods are thought to be bought in these hedonic markets. This compensating variation has therefore a countervailing effect on life satisfaction. In equilibrium, it is predicted that all public goods and public bads are capitalized in land (or rents) and wages and, consequently, life satisfaction is equalized across regions. However, this does not mean that the positive (negative) effect of a public good (bad) would not affect residents' well-being. It is just that a positive (negative) effect is equally distributed among them. Having said this, one has to take into consideration that, in reality, various restrictions, as well as moving and transaction costs, are likely to prevent complete arbitrage/equalization. Moreover, landowners (and employees with firm-specific investments) only have a costly exit option from locations that are negatively affected by a public bad or an externality. These residual effects are still captured in reports of subjective well-being studied across regions (see also Van Praag and Baarsma 2001). However, the life satisfaction approach is not restricted to these residual effects. In fact, it can be applied with any degree of compensation,

\footnotetext{
${ }^{8} \mathrm{~A}$ third possibility is to instrument the variance of the public good, which is an almost hopeless undertaking in the case of terrorism.
} 
as long as the channels of compensation are accounted for. ${ }^{9}$ As income, an important channel of compensation, is included in happiness functions anyway, it is mainly rent differentials that could have an offsetting impact. The life satisfaction approach is applied to the best advantage when there is no, or only little, compensation. In these situations, the hedonic market approach breaks down. In contrast, the life satisfaction approach works well. Compensation is most likely to be minor when annual intra- and interregional fluctuations are studied rather than variation across regions or countries. Empirically, this is possible in panel analyses as, e.g. conducted in our application in section 3 .

Geographical extension. A critical element of the analysis is the choice of the spatial units or regions across which changes in life satisfaction caused by externalities are identified or, in other words, the determination of the geographical boundaries of the externality of interest. ${ }^{10}$ For some externalities, the boundaries are obvious and the spatial choice does not pose any further problem. Noise nuisance, for example, though it might be perceived differently in different places and by different people, can be objectively measured and located. This is also true for other externalities that are of a technological kind, in particular externalities in the environmental realm. Likewise, in the case of publicly provided goods, politically defined boundaries are often the appropriate choice. For social externalities, like externalities of education, cultural amenities, crime or terrorism, it is far more difficult to draw boundaries. Terrorism, for example, is explicitly "designed to have far-reaching psychological repercussions beyond the immediate victim or target" (Hoffman 1998; see also Wilkinson 2000 , p. 12 , among others). In this case, one has to ask whether the climate of fear is confined to a legally or geographically defined region and where, if at all, empathy for the victims ends? This is a serious problem, as the estimated effects crucially depend on the spatial units chosen. Figure 1 illustrates this aspect. Suppose, for example, a bomb explodes in the crowded business district of a small Northern Irish town and kills a large number of civilians. This terrorist incidence can affect people's well-being in very different ways: for example, it can be taken as an indication of a new wave of terrorist attacks all over the British Isles and the atrocity shocks people everywhere to the same extent. In that case, it is quite likely that life satisfaction is depressed everywhere in Great Britain (or region B in figure 1) and in Northern Ireland (region A) to the same extent. This situation is depicted in figure 1a. The effect of the incident on individuals' well-being then cannot be identified across these two regions. If, on the other hand, only people in Northern Ireland are affected by an incident taking place in Northern Ireland and no spillovers occur (figure 1b), the average decrease in life satisfaction due to terrorism can be fully identified (it amounts to $\alpha$ in figure 1b). In many cases, reality is characterized by an intermediate case, whereby individuals living in region $\mathrm{B}$ are also affected, but to a lesser degree (as in figure 1c). Only the difference from the average

\footnotetext{
${ }^{9}$ Similarly, marginal implicit prices are underestimated in hedonic market analyses, which do not make allowances for simultaneous compensation in different markets (Blomquist et al. 1988; Freeman 2003, p. 410).

${ }^{10}$ An equivalent problem is the choice of adequate time units in panel analyses.
} 
impact, which an incident has in the two regions, can then be identified ( $\beta$ in figure $1 \mathrm{c}$ ). Therefore, the more incidents take place that only affect local residents, or alternatively, the lower the regional spillovers, the more appropriately the effect can be measured. While the average effect of an externality on life satisfaction varies with the spatial units chosen, the total effect (shaded areas in figure 1) can be captured completely with sufficiently broad boundaries. Obviously, a trade-off exists between the number of regions across which the effect is identified and their size. The problem of omitted variables is likely to increase with extending geographical boundaries. For example, in the case of terrorism, differences in national judicial systems, the political conditions, as well as biased reporting of terrorist attacks $^{11}$, make it difficult to evaluate utility losses due to terrorism in a cross-country setting. ${ }^{12}$

\section{FIGURE 1 ABOUT HERE}

The discussion makes clear that knowledge of the actual situation and accurate definition of the regions across which the utility loss is identified are essential. In the empirical part, we split the countries into three regions, namely the region including the capital, particularly terrorism-prone regions and the rest of the country. Many incidents in our data are clearly confined to the capital: Paris and London were plagued by attacks on foreign ambassadors, other diplomats and government officials, as well as headquarters or domestic branches of firms. Similarly, many incidents are clearly confined to a specific region because a regional terrorist group restricts its activities to its home region. Most of the attacks of the Front de Libération Nationale de la Corse (FLNC), for example, are perpetrated in Corsica rather than in continental France. Likewise, the Ulster Volunteer Force (UVF), its splinter group the Loyalist Volunteer Force (LVF) and the Ulster Defence Association (UDA), limit their activity largely to Northern Ireland. Hence, we identify utility losses in a combined crosssection and time-series analysis, whereby the cross-sectional units in the case of France are the regions Ile-de-France (which includes Paris), Provence-Alpes-Côte d'Azur (which includes Corsica in the Euro-Barometer Surveys Series) and the rest of France, Northern Ireland, Greater London and the rest of Great Britain in the case of the United Kingdom, and Great Britain, Northern Ireland and the Republic of Ireland in the case of the Northern Ireland 'Troubles'.

\footnotetext{
${ }^{11}$ A well-established problem connected with the measurement of terrorist incidents and casualties is the 'reporting bias,' i.e. the fact that reported numbers from authoritarian and less developed countries are too low, because authorities themselves do not know the correct numbers or deliberately bias their reporting (e.g. Miller 1994).

${ }^{12}$ In the case of a pure global public good, identification is also no longer possible, because the appropriate geographical boundary extends over the whole world.
} 


\section{Effects of Terrorism on Life Satisfaction}

In the following, we use the life satisfaction approach to measure utility losses due to terrorism. The fundamental reason for the existence of the state is to overcome the brutish and welfare-decreasing fight of everyone against everyone. One of the basic elements of any constitutional consensus is therefore to grant government the unique right to use force. Terrorists deliberately undermine this consensus by using force on other people. Thus, it is a constitutional task of the government to deal with terrorism. This, of course, involves public spending. It is therefore necessary to know the costs imposed on people by terrorist activities. Only then can the government decide what resources should be mustered to deal with terrorism. This holds even if the government is not viewed as a social-welfare maximizing agent, but is rather seen to act in a setting characterized by political competition, most importantly the need to stay in power.

\subsection{Data}

Our main variables are people's self-reported life satisfaction and income, as well as various indicators of terrorism. The former are taken from the Euro-Barometer Survey Series (19701999), which interviews a random cross-section sample of Europeans each year. The variable life satisfaction is the categorical response to the following question: "On the whole, are you very satisfied [4], fairly satisfied [3], not very satisfied [2], or not at all satisfied [1] with the life you lead?" The question was asked in the years between 1973 and 1998, with the exception of the years 1974 and 1996. The observations are assigned to the regions of interest, according to the respondents' place of residence. However, all observations from south-east France in 1987 and 1990 are excluded because they cannot be split up between the regions Provence-Alpes-Côte d'Azur and the 'Rest of France.' Similarly, observations from the year 1973 are not included in the estimations for the British Isles, because the Northern Irish subsample is included in the sample of Great Britain.

The Euro-Barometer Survey Series also contains information concerning the income situation of the respondents; concretely, they are classified into between 6 and 15 classes of household income. The class size and number of classes varies considerably between countries and surveys. Therefore, we translate the original income class information into a number, which represents the value at the mid-point of the respective class interval. The values are deflated by consumer price indices and converted into Euros (using the irrevocable exchange rates fixed at the end of 1998 in the case of France and Ireland, and the 1998 Pound-Euro exchange rate in the case of the United Kingdom). Because the highest income class is open-ended, respondents that fall into this income class are excluded. This exclusion results in smaller estimated coefficients for income and hence larger compensations compared to the full sample. In order to capture the effect of household size on equivalence income, the square root of household size is included in the estimation equations. Further, a set of personal 
characteristics is incorporated, including sex, age, education, number of children, marital status, employment status and type of community the respondent lives in. We include only observations where the respondent's age and sex are known and the respondent is over 14 years old. This leads to a total of 136,909 observations, namely 40,803 observations for Great Britain, 12,387 for Northern Ireland, 40,488 for the Republic of Ireland and 43,231 for France, respectively. ${ }^{13}$

In order to capture the intensity of the terrorist activity in different regions and years, we use two different terrorism indicators: the number of reported incidents in France and the United Kingdom and the number of persons killed in the Republic of Ireland and the United Kingdom due to the Northern Ireland conflict.

The first indicator is constructed on the basis of the RAND-St. Andrews Chronology of International Terrorism, comprehending the years 1968 to 1996 (see e.g. Hoffman and Hoffman 1995; made publicly available by the Oklahoma City National Memorial Institute for the Prevention of Terrorism on its homepage (www.mipt.org)) and the Terror Attack Database of the International Institute for Counter-Terrorism (www.ict.org.il) for the years 1986 up to the present day. Every reported incident contains a short description with - in the majority of cases - the exact location of the incident. This allows us to assign the incident to a particular region (only 16 incidents cannot be attributed to a region in the case of the United Kingdom and five in the case of France). Both databases are restricted to international terrorism. However, international terrorism is broadly defined and includes attacks by Corsican and Northern Irish separatist groups in France and Great Britain, as well as attacks by domestic terrorist groups whenever foreigners are involved. In France, for example, several attacks are recorded for which the Action Directe (AD) claimed credit, especially in the mid 1980s when the AD tried to ally themselves with the German Rote Armee Fraktion (RAF). But also many state-sponsored terrorist activities took place on French territory. An example is the murder of the former Iranian Prime Minister Shapour Bakhtiar in Paris in 1991 by a hit-squad which, according to the French investigating judge was carried out under the direct orders of the Iranian regime (Wilkinson 2000, p. 66). Furthermore, France was plagued with the spillover of Basque terrorism into France, the spillover of activities by the Groupe Islamic Armée (GIA) and other incidents related to the Middle East. A large fraction of reported incidents in Great Britain were committed by the Provisional Republican Army (PIRA) and to a lesser extent by the Irish National Liberation Army (INLA). The first of many sporadic, but mostly spectacular, PIRA attacks was a bomb attack in London in March 1973, resulting in one death and almost 200 injured. As with France, the United Kingdom was

\footnotetext{
${ }^{13}$ Life satisfaction data for the countries of interest are available for 153,426 observations; 856 observations are excluded because either respondents' age or sex are unknown or his/her age is below 14 years. The omission of the year 1973 in the case of the British Isles and the observations from south-east France in the years 1987 and 1990 further reduces the number of observations by 3,247. Finally, 12,414 observations are excluded due to the fact that respondents belong to the highest income class.
} 
afflicted by the spillover of Middle East terrorism. Figure 2 depicts the number of incidents in France and the United Kingdom; while the number of attacks in France is slightly on the decrease, no clear trend is visible in the United Kingdom.

\section{FIGURE 2 ABOUT HERE}

The 'Troubles' in Northern Ireland, especially the violence in Northern Ireland itself, are only partly captured by the number of international terrorism incidents. As an alternative indicator, we therefore use the number of deaths resulting from the conflict in Northern Ireland. The information regarding the deaths is compiled by Sutton (1994; an updated index is provided by the Conflict Archive on the Internet (www.cain.ulst.ac.uk)). This indicator is not restricted to terrorism in particular, but includes political violence in general. Though the PIRA was always the highest taker of life, killing civilians, security forces and prison staff, the UDA and UVF were also very active; the interaction between these groups is generally referred to as sectarian 'tit-for-tat' exchanges (McKittrick and McVea 2001, p. 109-110). Feuds between the Provisional and Official IRA in 1975 and between the UDA and UVF in 2000, as well as hunger strikes on the part of imprisoned IRA members in 1981, added to the death toll. On the other hand, a considerable number died at the hand of security forces. British paratroopers killed 14 demonstrators on the Bloody Sunday of 1972, British intelligence played a part in the Dublin and Monaghan bombing in 1974, and the army's undercover SAS regiment staged ambushes in which IRA members - and innocent bystanders - were shot, to name but a few examples.

\section{FIGURE 3 ABOUT HERE}

As can be seen from figure 3, the number of deaths in Northern Ireland plummeted in 1977 but otherwise remained high for the whole period under consideration. This corresponds to the observations of McKittrick and McVea (2001, p. 133) that 1977 "was a true turning-point in that violence fell dramatically, and would never again rise to the scale experienced in the 1971-76 period."

\subsection{Empirical Strategy}

Based on the described data sets, micro-econometric happiness functions are specified. Individual life satisfaction itr $_{\text {, }}$, i.e. the life satisfaction of individual $i$ living in region $r$ at time $t$, is explained by differences in the level of terrorism ${ }_{t r}$ across regions and over time, the individual's household income $_{i t r}$ other personal characteristics $\bar{Z}_{i t r}$, as well as region and time fixed effects $D_{r}$ and $D_{t}$, respectively. The specification is summarized in the following equation:

(1) Life satisfaction itr $=\beta_{0}+\beta_{1}$ terrorism $_{t r}+\beta_{2} \ln \left(\right.$ income $\left._{i t r}\right)+\beta_{3} \bar{Z}_{i t r}+\beta_{4} D_{t}+\beta_{5} D_{r}+\varepsilon_{i t r}$. 
Throughout the paper, we use a robust estimator of variance, because random disturbances are potentially correlated within groups or clusters, here cross-sectional units fora specific year. ${ }^{14}$

We tested specifications with different functional forms because there is no a priori reason to favor one specific functional relationship between terrorism and life satisfaction over another. In particular, we studied the sensitivity of the results, using two-year and three-year moving averages, the natural logarithm, the natural logarithm of the aforementioned moving averages of the terrorism indicators, and these indicators squared, as well as incidents and fatality rates. As the results ${ }^{15}$ were robust with regard to sign, magnitude and statistical significance, we used the explanatory variables in the simplest form, i.e. the number of incidents and the number of fatalities. Various functional forms are also possible for the variable income. Diminishing marginal utility of income was affirmed by a significant negative effect of income squared on life satisfaction for all countries and periods considered. Hence, household income is included in the estimations in its natural logarithm. Finally, no heterogeneity of preferences across income classes with regard to terrorism seems to exist. The respective interaction terms were not statistically significantly different from zero and are, therefore, not included in the following estimations.

\subsection{Results}

Basic results. The main results for the variables capturing terrorism and income are presented in table 1. The full micro-econometric life satisfaction functions estimated for France, the United Kingdom, and the United Kingdom and Ireland are shown in the appendix in table A.1. The estimated coefficients for the control-variables are comparable to earlier findings (see e.g. Di Tella et al. 2001 for results based on the Euro-Barometer Survey Series).

As can be seen from table 1, terrorism negatively affects people's self-reported life satisfaction in a sizeable and statistically significant way. In France, an increase in one standard deviation in the number of recorded terrorist incidents, i.e. an increase of 10.324 incidents, lowers life satisfaction by 0.029 points on the four-point scale. For the United Kingdom, with a standard deviation of 7.360 incidents, the respective figure is 0.050 points; and for the United Kingdom and the Republic of Ireland, with a standard deviation of 53.670 fatalities, it is 0.041 . These are large effects, indicating that a reduction of the terrorist threat by one standard deviation is equivalent to shifting 2.9 percent of the French population (or 5.0 of the British / 4.1 of the Irish population) from, for example not very satisfied [2] to fairly satisfied [3] with life. These effects in terms of life satisfaction offer one way of valuing a public bad with the life satisfaction approach. They could now be compared with estimates for other public goods or bads. For a valuation in monetary terms, estimates for the marginal

\footnotetext{
${ }^{14}$ Ignoring the clustering in the estimation model is likely to produce downward biased standard errors, due to the effects of aggregate variables on individual data (Moulton 1990). To get unbiased standard errors for the aggregate variable terrorism $_{\text {itr }}$, the regions in a specific year are used as sampling units.

${ }^{15}$ They are available from the authors on request.
} 
utility of income have to be taken into consideration. Table 1 includes the respective estimations. Coefficients for (household) income are positive and highly statistically significant. The partial correlation between log income and life satisfaction for France is 0.218 . Thus, when income is doubled, on average, a 0.151 points higher life satisfaction is reported.

\section{TABLE 1 ABOUT HERE}

Sensitivity analyses. To check the validity of the results, two tests of robustness are performed: (i) the influence of high values of the indicators reflecting the intensity of terrorism is analyzed; and (ii) macro-variables capturing the economic situation are included in order to address issues of simultaneity.

(i) In 1982, an unprecedented number of 66 terrorist attacks took place in Paris, a number never again reached in subsequent years (see figure 2). Similarly, in Northern Ireland, recorded fatalities in the years 1975 and 1976 by far outnumbered the fatalities of subsequent years (see figure 3 ). In order to investigate whether the negative correlation between terrorism and life satisfaction is largely driven by these observations, we exclude them from the estimation. It is debatable whether this exclusion is reasonable. If people perceive large changes in the intensity of terrorist campaigns rather than small ones, the inclusion of these extreme values is crucial for the identification of the effect terrorism has on life satisfaction. Nevertheless, the robustness of the coefficients with regard to the exclusion of high values enhances the reliance on the validity of the estimates. In both cases, the magnitude of the respective coefficients increases, while the statistical significance decreases if the outliers are excluded. Without the observation of the year 1982 for the region "Ile-de-France", the estimated coefficient for France is -0.005 per 10 incidents (compared to -0.028 in table 1 ); the $\mathrm{t}$-value decreases from -4.03 to -3.55 and hence the probability that the true coefficient is zero increases from 0.0 percent to 0.1 percent. The picture is somewhat different in the case of the estimations for the Northern Ireland conflict: though the magnitude of the estimated coefficient is robust, the t-value decreases from -4.00 to -1.11 , and the probability that the true coefficient is zero increases from 0.0 percent to 27.2 percent. This latter result indicates that in fact the aforementioned turning point in violence helps to identify the negative effect of the Northern Ireland conflict on individuals' well-being.

(ii) One might expect the negative correlation between terrorism and life satisfaction to be spurious because the state of the economy may be (negatively) correlated with the intensity of terrorist campaigns. If a high level of terrorist activity is generally accompanied by a slackening of the economy, people may report lower life satisfaction because of fearing job reductions rather than terrorist attacks. Such a negative relationship between economic and terroristic activity is probable and can be due to two different causal processes. On the one hand, bad economic conditions and high levels of unemployment may facilitate the 
recruitment of rank and file activists. On the other hand, terrorism may dampen economic activity. McKittrick and McVea (2001, p. 28) presume the first causal relationship for Northern Ireland when writing that "[i]t is scarcely a coincidence that some of the areas which featured prominently in the troubles $[\ldots]$ were among those where $[\ldots]$ high unemployment persisted." However, systematic evidence for the Middle East does not indicate a causal connection from poverty to terrorism (Krueger and Maleckova 2003). The other causal connection is better documented. Over the last few years, economic scholars have analyzed the effects terrorist acts have on various parts of the economy. Empirical research has shown that terrorist acts significantly reduce the number of tourists (see Enders and Sandler 1991 for Spain; Enders et al. 1992 for Greece, Italy and Austria; and Drakos and Kutan 2003 for Greece, Turkey and Israel), lower the inflow of foreign direct investment (see Enders and Sandler 1996 for Spain and Greece), decrease bilateral trade (Nitsch and Schumacher 2002), have significant negative impact on aggregate consumption and savings (see Fielding 2003 for Israel) as well as gross domestic income and stock prices (see Abadie and Gardeazabal 2003 for the Basque Country). In order to control for the simultaneity between high levels of political violence and the slackening of the economy, we include GDP per capita (in $€ 1,000$ ) and the number of unemployed per capita as additional explanatory variables in the microeconometric happiness function for the United Kingdom, as well as for the United Kingdom and the Republic of Ireland. Table 2 shows the estimation results.

\section{TABLE 2 ABOUT HERE}

Coefficients for both indicators of terrorism remain of similar magnitude and statistical significance when business cycle effects are controlled for. The results for the control variables are much less clear-cut. GDP per capita is statistically significantly correlated with life satisfaction but, in the case of the United Kingdom, it has an unexpected negative sign. ${ }^{16}$ Prevailing unemployment levels have a sizeable negative effect on life satisfaction, though it is not statistically significant. However, it is important to note that individuals' income and employment status are held constant. Though other omitted variables could possibly exist, the robustness of the terrorism indicators enhances our confidence that the estimated correlations are not spurious.

Monetization. With the estimated coefficients of the micro-econometric happiness function for terrorism $\left(\beta_{1}\right)$ and income $\left(\beta_{2}\right)$, the people's willingness-to-pay for a reduction in terrorism can be calculated. The willingness-to-pay is measured by the compensating surplus ( $C S$ ). The $C S$ is the decrease in income necessary to hold utility constant. In other words, the $C S$ is the solution to the following expression:

$$
v\left(\text { income }_{0} ; \text { terrorism }_{0}\right)=v\left(\text { income }_{0}-\text { CS; } \text { terrorism }_{1}\right),
$$

\footnotetext{
${ }^{16}$ While the result is likely to be a statistical artefact, Ruhm (2000) provides systematic evidence for a negative correlation between economic upturns and individuals' health.
} 
where $v(\cdot)$ is the indirect utility function, income $_{0}$ the initial household income, terrorism 0 the initial level of terrorism and terrorism $m_{1}$ the level after a hypothetical reduction. According to the specification of the micro-econometric happiness function expressed in equation (1) and the definition of the $C S$ in equation (2), the $C S$ can be computed as follows:

$$
C S=\text { income }_{0}-e^{\frac{\beta_{1} \cdot\left(\text { terrorism }_{0}-\text { terrorism }_{1}\right)+\beta_{2} \cdot \ln \left(\text { income }_{0}\right)}{\beta_{2}}} .
$$

Estimates are presented for people living in particular terrorism-prone regions. Specifically, we calculate the hypothetical willingness-to-pay for residents of Paris and London for a reduction in the number of incidents to bring them on a par with the rest of France (except for the region Provence-Alpes-Côte d'Azur) and the rest of Great Britain respectively, as well as for the residents of Northern Ireland for a reduction in the number of fatalities to be on a par with Great Britain and the Republic of Ireland. All CSs are calculated for an individual with the average annual household income. The results are shown in table 3.

\section{TABLE 3 ABOUT HERE}

According to the results shown in table 3, a resident of Paris would be willing to pay around $14 \%$ of his income for a reduction in terrorist activity to a level that prevails in the more peaceful parts of the country, while a resident of London would be willing to forego around $32 \%$ of his income and a resident of Northern Ireland around $41 \%$. These estimates are surprisingly high. Before a likely source of error is discussed that distorts estimated CSs upwards, the estimates have to be put into perspective.

The result for France, on the one hand, is comparable to the compensations which Blomquist et al. (1988) identified on the labor and housing market in the United States for individuals living in the county with the highest rate of violent crime vis à vis individuals living in the county with the least crime. The compensation amounts to $\$ 2,267$, or to $11 \%$ of annual household income. The result for Northern Ireland, on the other hand, to some extent reflects the ferocity of the conflict. The number of fatalities depicted in figure 3 gives a sense of this ferocity. Fay et al. (1999, p. 204) estimate that around two thirds of the Northern Irish population live in households where someone has been injured in a conflict related incident; the number of around 30,000 republican and loyalist ex-prisoners illustrates how deeply society was permeated by paramilitarism (McKittrick and McVea 2001, p. 150). In addition, curfews, rigorous house-to-house searches, several thousand people fleeing their homes and large-scale riots accompanied the worst times of the conflict. The statements of two senior policemen summarize the situation: "The country stared into the face of great difficulty and crept right to the edge of the abyss," and "We were on the brink of all-out civil war" (cited in McKittrick and McVea 2001, p. 211).

Another reason for a high willingness-to-pay for lower terrorist activity might be people's difficulty in assessing terrorism-risks. According to Viscusi and Zeckhauser (2003), people 
are subject to a propensity to predict worst-case scenarios and are prone to anomalies known from other risk perception contexts. Hindsight bias and embeddedness effects are particularly evident for terrorism-risk perception. Downes-Le Guin and Hoffman (1993) contend that much higher probabilities are accorded to terrorism than to other life-threatening acts. Sunstein (2003), on the other hand, finds that individuals focus on the badness of the outcome rather than on the probability that it will occur. The "probability neglect" results in fear that greatly exceeds discounted harm. These results suggest that people are far more concerned with terrorism than with objectively larger risks, and that fear of terrorism might be largely determined by the salience of the topic. Intense media coverage of terrorist acts ensures that terrorism is very present in people's minds. The high number of fatalities in violent periods of the conflict in Northern Ireland, for example, means "that hardly a newspaper or evening television programme did not bring news of either a killing or a funeral" (McKittrick and McVea 2001, p. 94), and that "the local television news seemed to consist of nothing except more and more violence, the grieving bereaved, and threats of more to come" (McKittrick and McVea 2001, p. 194).

Marginal utility of income: source of error and priority for future research. The marginal utility of income is crucial for the calculation of the willingness-to-pay or willingness-toaccept respectively. Hence, if the marginal utility of income is not estimated correctly, estimates of the welfare measures are distorted. There are at least two problems that hamper the estimation of the marginal utility of income. Firstly, many surveys - and especially the Euro-Barometer Survey Series used here - provide very crude information regarding people's income. Measurement errors in the explanatory variable, or in this case household income, bias the estimation coefficient towards zero. ${ }^{17}$ Estimated welfare measures are thereby distorted upwards. Secondly, research has shown that people adapt to higher income or consumption levels. While an increase in income initially provides extra pleasure, it is usually only transitory and the higher utility wears off (van Praag 1993; Easterlin 2001; Stutzer 2004). In micro-econometric happiness functions, mainly the long-run marginal utility, i.e. marginal utility after adaptation, is captured. Therefore, the utility consequences of changes in income are underestimated. This, too, biases estimated welfare measures upwards.

Does all this invalidate the life satisfaction approach? On the one hand, more precise information of respondents' income situation in surveys would clearly enhance the validity of the approach. Further, the investigation of utility or life satisfaction consequences of exogenous income changes is an important area for future research. On the other hand, a comparison of the importance attached by individuals to different public goods is not affected by an imprecise measurement of the marginal utility of income. If the value of public goods is

\footnotetext{
${ }^{17}$ However, the directions of bias cannot easily be determined a priori in the more general case of more than one poorly measured explanatory variable. Other potential candidates for poor measurement are our indicators of terrorist activity: the number of incidents and fatalities. Therefore, we cannot rule out that the estimated coefficients for terrorist activity are biased upwards.
} 
expressed in terms of life satisfaction, respective estimates can be directly put in perspective to spending on these goods. This already allows for an assessment of the relative efficiency of pubic resource allocation. Thus, the life satisfaction approach is able to reveal important information on people's preferences for public goods.

\section{Concluding Remarks}

This paper discusses the life satisfaction approach, a new approach to elicit people's preferences for public goods. A growing literature in economics uses reported subjective well-being data; this research has shown that self-reported life satisfaction is an empirically adequate and valid approximation for utility. It is therefore an obvious, but up to now rarely pursued, strategy to evaluate the utility consequences of externalities and public goods directly in utility terms. Moreover, together with estimates for the marginal utility of income, the utility consequences can be monetized. A look at the weaknesses of the most prominent methods in economics to evaluate public goods highlights the strengths of the life satisfaction approach. Revealed preference methods, on the one hand, are based on stringent assumptions, crucial elements are inherently difficult to measure and non-use values cannot be captured. By way of contrast, the life satisfaction approach is not based on observed behavior, and thus the underlying assumptions are less restrictive and non-use values can - to some extent - be measured. On the other hand, the hypothetical nature of contingent valuation may entail unreliable results and strategic behavior. The life satisfaction approach obviates these problems, as individuals are not asked to value the public good directly but to evaluate their general life satisfaction. The respondents' reported life satisfaction is then correlated with the variable of interest.

In an exploratory application of the life satisfaction approach, estimates for people's utility losses caused by terrorist activity are presented. The results for France, Great Britain and the Republic of Ireland demonstrate that terrorist campaigns depress the life satisfaction of the individuals in the affected regions in a sizeable way. This effect is robust when controlling for possible simultaneity of terrorism and bad economic conditions. In the case of the Northern Ireland conflict, however, the effect is mainly identified by the turning point in violence between the years 1976 and 1977. Smaller changes in the level of political violence in other years do not significantly affect life satisfaction. In France, the result is robust with regard to the exclusion of outliers.

Though the life satisfaction is a promising approach for the valuation of public goods, the paper addresses several issues that are important for the adequate identification of utility losses. Firstly, the life satisfaction approach, like revealed preference methods, is not immune to possible spurious correlations that are the result of omitted variables. Secondly, people affected by negative externalities are possibly compensated by higher wages and lower rents; 
these compensations countervail the original utility consequences caused by the externality. The life satisfaction approach is neither restricted to situations where compensation in private markets takes place nor to situations without such compensation. However, in cross-section analyses, potential channels of compensation need to be controlled for. Thirdly, a critical element of the analysis is the choice of the cross-sectional units (and time units as well) across which changes in life satisfaction caused by externalities are identified. In case the externality transcends the boundaries of the units and affects life satisfaction in the adjacent units, the effect on life satisfaction is underestimated.

The estimated effects of terrorism in terms of life satisfaction are of a reasonable magnitude. For a change in incidents by one standard deviation in France, the effect amounts to one seventh of being unemployed. Due to probably too low estimates for the marginal utility of income, estimated willingness-to-pay for a reduction of terrorism, however, is very high. Estimates range from $15 \%$ in France to $41 \%$ in Northern Ireland when the most terrorist prone regions are compared to the least terrorist prone regions. These estimates reveal a problem that needs to be addressed by future research. Marginal utility of income is presumably underestimated in micro-econometric happiness functions for at least two reasons. Firstly, whereas micro-econometric happiness functions capture long run marginal utility of income, i.e. marginal utility after adaptation, willingness-to-pay corresponds to marginal utility of a change in income. Secondly, crude measurement of household income in surveys biases the estimated coefficient towards zero. However, a comparison of differences in utility consequences, caused by different public goods and bads, is thereby unaffected. Moreover, as these problems can be addressed, they do not invalidate the life satisfaction approach.

\section{REFERENCES}

Abadie, Alberto and Javier Gardeazabal (2003). The Economic Costs of Conflict: A Case Study of the Basque Country. American Economic Review 93(1): 113-132.

Arrow, Kenneth J. (1958). Utilities, Attitudes, Choices: A Review Note. Econometrica 26(10): 1-23.

Arrow, Kenneth J., Robert S. Solow, Edward Leamer, Paul Portney, Ray Radner and Howard Schuman (1993). Report of the NOAA-Panel on Contingent Valuation. Federal Register 58(10): 4601-4614.

Blomquist, Glenn C., Mark C. Berger and John P. Hoehn (1988). New Estimates of Quality of Life in Urban Areas. American Economic Review 78(1): 89-107.

Bresnahan, Brian W., Mark Dickie and Shelby Gerking (1997). Averting Behavior and Urban Air Pollution. Land Economics 73(3): 340-357.

Carson, Richard T., Nicholas E. Flores and Norman F. Meade (2001). Contingent Valuation: Controversies and Evidence. Environmental and Resource Economics 19(2): 173-210.

Carson, Richard T., Robert C. Mitchell, W. Michael Hanemann, Raymond J. Kopp, Stanley Pressers and Paul A. Ruud (2003). Contingent Valuation and Lost Passive Use: Damages from the Exxon Valdez Oil Spill. Environmental and Resource Economics 25(3): 257-286.

Chay, Kenneth Y. and Michael Greenstone (2001). Does Air Quality Matter? Evidence from the Housing Market. The Center for Labor Economics Working Paper No. 33, University of California, Berkeley. 
Clawson, Marion and Jack L. Knetsch (1966). Economics of Outdoor Recreation. London and Baltimore: John Hopkins University Press.

Di Tella, Rafael, Robert J. MacCulloch and Andrew J. Oswald (2001). Preferences over Inflation and Unemployment: Evidence from Surveys of Happiness. American Economic Review 91(1): 335-341.

Di Tella, Rafael, Robert MacCulloch and Richard Layard (2002). Income, Happiness and Inequality as Measures of Welfare. Mimeo, Harvard Business School.

Diamond, Peter A. and Jerry A. Hausman (1994). Contingent Valuation: Is Some Number Better Than No Number? Journal of Economic Perspectives 8(4): 45-64.

Diener, Ed, Eunkook M. Suh, Richard E. Lucas and Heidi L. Smith (1999). Subjective Well-Being: Three Decades of Progress. Psychological Bulletin 125(2): 276-302.

Downes-Le Guin, Theodore and Bruce Hoffman (1993). The Impact of Terrorism on Public Opinion, 1988 to 1989. Santa Monica, CA: RAND Corporation.

Drakos, Konstantinos and Ali M. Kutan (2003). Regional Effects of Terrorism on Tourism in Three Mediterranean Countries. Journal of Conflict Resolution 47(5): 621-641.

Due, John F. and Ann F. Friedlaender (1973). Government Finance: Economics of the Public Sector. 5th ed. Homewood: Irwin.

Easterlin, Richard A. (2001). Income and Happiness: Towards an Unified Theory. Economic Journal 111(473): 465-484.

Enders, Walter and Todd Sandler (1991). Causality between Transnational Terrorism and Tourism: The Case of Spain. Terrorism 14(1): 49-58.

Enders, Walter and Todd Sandler (1995). Terrorism: Theory and Applications. In: Keith Hartley and Todd Sandler (eds). Handbook of Defense Economics, vol. 1. Amsterdam, New York and Oxford: Elsevier: 213249.

Enders, Walter and Todd Sandler (1996). Terrorism and Foreign Direct Investment in Spain and Greece. Kyklos 49(3): 331-352.

Enders, Walter, Todd Sandler and Gerald F. Parise (1992). An Econometric Analysis of the Impact of Terrorism on Tourism. Kyklos 45(4): 531-554.

Fay, Marie-Therese, Mike Morrissey and Marie Smyth (1999). Northern Ireland's Troubles: The Human Costs. London: Pluto Press.

Ferrer-i-Carbonell, Ada and Paul Frijters (2004). How Important Is Methodology for the Estimates of the Determinants of Happiness? Economic Journal, forthcoming.

Fielding, David (2003). Counting the Cost of the Intifada: Consumption, Saving and Political Instability in Israel. Public Choice 116(3-4): 297-312.

Freeman, A. Myrick, III (2003). The Measurement of Environmental and Resource Values: Theory and Methods. Washington, D.C.: Resources for the Future.

Frey, Bruno S. and Simon Luechinger (2003). How to Fight Terrorism: Alternatives to Deterrence. Defence and Peace Economics 14(4): 237-49.

Frey, Bruno S. and Alois Stutzer (2002a). Happiness and Economics: How the Economy and Institutions Affect Well-Being. Princeton and Oxford: Princeton University Press.

Frey, Bruno S. and Alois Stutzer (2002b). What Can Economists Learn from Happiness Research? Journal of Economic Literature 40(2): 402-35.

Frey, Bruno S. and Alois Stutzer (2003). Testing Theories of Happiness. IEW Working Paper No. 147, University of Zurich.

Hanemann, W. Michael (1994). Valuing the Environment through Contingent Valuation. Journal of Economic Perspectives 8(4): 19-43. 
Hausman, Jerry A., Gregory K. Leonard and Daniel McFadden (1995). A Utility-Consistent, Combined Discrete Choice and Count Data Model: Assessing Recreational Use Losses Due to Natural Resource Damage. Journal of Public Economics 56(1): 1-30.

Hoffman, Bruce (1998). Inside Terrorism. New York: Columbia University Press.

Hoffman, Bruce and Donna K. Hoffman (1995). The Rand-St. Andrews Chronology of International Terrorism, 1994. Terrorism and Political Violence 7(4): 178-229.

Kahneman, Daniel (1994). New Challenges to the Rationality Assumption. Journal of Institutional and Theoretical Economics 150(1): 18-36.

Kahneman, Daniel (1999). Objective Happiness. In: Daniel Kahneman, Ed Diener and Norbert Schwarz (eds). Well Being: The Foundations of Hedonic Psychology. New York, NY: Russell Sage Foundation: 3-25.

Kahneman, Daniel, Ed Diener and Norbert Schwarz (eds) (1999a). Well-Being: The Foundations of Hedonic Psychology. New York, NY: Russell Sage Foundation.

Kahneman, Daniel and Jack L. Knetsch (1992). Valuing Public Goods: The Purchase of Moral Satisfaction. Journal of Economics and Management 22(1): 57-70.

Kahneman, Daniel, Ilana Ritov and David A. Schkade (1999b). Economic Preferences or Attitude Expressions?: An Analysis of Dollar Responses to Public Issues. Journal of Risk and Uncertainty 19(1-3): 203-235.

Krueger, Alan B. and Jitka Maleckova (2003). Education, Poverty and Terrorism: Is There a Causal Connection? Journal of Economic Perspectives 17(4): 119-144.

Layard, Richard (2004). Happiness. Mimeo, London School of Economics.

McKittrick, David and David McVea (2001). Making Sense of the Troubles. London: Penguin Books.

Miller, Abraham H. (1994). Comment on Terrorism and Democracy. Terrorism and Political Violence 6(4): 435-439.

Moulton, Brent R. (1990). An Illustration of a Pitfall in Estimating the Effects of Aggregate Variables on Micro Unit. Review of Economics and Statistics 72(2): 334-38.

Nitsch, Volker and Dieter Schumacher (2002). Terrorism and Trade. Paper prepared for the workshop on the Economic Consequences of Global Terrorism, Berlin, June 14 - 15, 2002.

Parsons, George R. (2003). The Travel Cost Model. In: Patricia A. Champ, Kevin J. Boyle and Thomas C. Brown (eds). A Primer on Nonmarket Valuation. Dordrecht, NL: Kluwer Academic Publishers: Ch. 9.

Pommerehne, Werner W. (1987). Präferenzen für öffentliche Güter. Ansätze zu ihrer Erfassung. Tübingen: Mohr (Siebeck).

Portney, Paul R. (1994). The Contingent Valuation Debate: Why Economists Should Care. Journal of Economic Perspectives 8(4): 3-17.

Rabin, Matthew (1998). Psychology and Economics. Journal of Economic Literature 36(1): 11-46.

Randall, Alan (1994). A Difficulty with the Travel Cost Method. Land Economics 70(1): 88-96.

Rehdanz, Katrin and David Maddison (2003). Climate and Happiness. Research Unit Sustainability and Global Change Working Paper No. FNU-20, Centre for Marine and Climate Research, Hamburg University.

Rosen, Sherwin (1974). Hedonic Prices and Implicit Markets: Product Differentiation in Pure Competition. Journal of Political Economy 82(1): 34-55.

Ruhm, Christopher J. (2000). Are Recessions Good for Your Health? Quarterly Journal of Economics 115(2): $617-650$

Sandler, Todd and Walter Enders (2004). An Economic Perspective on Transnational Terrorism. European Journal of Political Economy, forthcoming.

Sandvik, Ed, Ed Diener and Larry Seidlitz (1993). Subjective Well-Being: The Convergence and Stability of Self-Report and Non-Self-Report Measures. Journal of Personality 61(3): 317-342. 
Schelling, Thomas C. (1968). The Life You Save May Be Your Own. In: Samuel B. Chase (ed.). Problems in Public Expenditure Analysis. Washington D.C.: The Brookings Institution: 127-176.

Smith, V. Kerry and Laura L. Osborne (1996). Do Contingent Valuation Estimates Pass a "Scope" Test? A Meta-Analysis. Journal of Environmental Economics and Management 31(3): 287-301.

Stutzer, Alois (2004). The Role of Income Aspirations in Individual Happiness. Journal of Economic Behavior and Organization, forthcoming.

Sunstein, Cass R. (2003). Terrorism and Probability Neglect. Journal of Risk and Uncertainty 26(2-3): 121-136.

Sutton, Malcolm (1994). Bear in Mind These Dead .... An Index of Deaths from the Conflict in Ireland 19691993. Belfast: Beyond the Pale Publications.

van Praag, Bernard M. S. (1993). The Relativity of the Welfare Concept. In: Martha Nussbaum and Amartya Sen (eds). The Quality of Life. Oxford, New York, Toronto and Melbourne: Oxford University Press and Clarendon Press: 362-385.

Veenhoven, Ruut (1993). Happiness in Nations: Subjective Appreciation of Life in 56 Nations 1946-1992. Rotterdam: Erasmus University Press.

Viscusi, W. Kip and Richard J. Zeckhauser (2003). Sacrificing Civil Liberties to Reduce Terrorism Risks. Journal of Risk and Uncertainty 26(2-3): 99-120.

Welsch, Heinz (2002). Preferences over Prosperity and Pollution: Environmental Valuation Based on Happiness Surveys. Kyklos 55(4): 473-494.

Wilkinson, Paul (2000). Terrorism Versus Democracy: The Liberal State Response. London and Portland, OR: Frank Cass.

Zeckhauser, Richard J. and Anthony C. Fisher (1976). Averting Behavior and External Diseconomies. Kennedy School Discussion Paper No. 41D, Harvard University. 
Table 1. Terrorism and life satisfaction in France, the United Kingdom and the Republic of Ireland; summary

\begin{tabular}{|c|c|c|c|c|c|c|}
\hline \multirow{3}{*}{$\begin{array}{l}\text { Dependent Variable } \\
\text { Life satisfaction }\end{array}$} & \multicolumn{2}{|c|}{ France } & \multirow{2}{*}{\multicolumn{2}{|c|}{$\begin{array}{c}\text { United Kingdom } \\
\text { 1975-1998 }\end{array}$}} & \multirow{2}{*}{\multicolumn{2}{|c|}{$\begin{array}{c}\text { U.K. and Ireland } \\
1975-1998\end{array}$}} \\
\hline & \multicolumn{2}{|c|}{ 1973-1998 } & & & & \\
\hline & Coefficient & t-value & Coefficient & t-value & Coefficient & t-value \\
\hline \multicolumn{7}{|l|}{ Terrorism indicators } \\
\hline Number of incidents (in 10s) & $-0.028 * *$ & -4.03 & $-0.068 * *$ & -3.25 & & \\
\hline Number of fatalities (in 100s) & & & & & $-0.077 * *$ & -4.00 \\
\hline \multicolumn{7}{|l|}{ Income } \\
\hline $\ln$ (income) & $0.218 * *$ & 17.22 & $0.144^{* *}$ & 16.66 & $0.128^{* *}$ & 17.57 \\
\hline Individual characteristics & \multicolumn{2}{|c|}{ Yes } & \multicolumn{2}{|c|}{ Yes } & \multicolumn{2}{|c|}{ Yes } \\
\hline Year dummies & \multicolumn{2}{|c|}{ Yes } & \multicolumn{2}{|c|}{ Yes } & \multicolumn{2}{|c|}{ Yes } \\
\hline Region dummies & \multicolumn{2}{|c|}{ Yes } & \multicolumn{2}{|c|}{ Yes } & \multicolumn{2}{|c|}{ Yes } \\
\hline Constant & \multicolumn{2}{|c|}{ Yes } & \multicolumn{2}{|c|}{ Yes } & \multicolumn{2}{|c|}{ Yes } \\
\hline Number of observations & \multicolumn{2}{|r|}{43,231} & \multicolumn{2}{|r|}{53,190} & \multicolumn{2}{|r|}{93,678} \\
\hline Number of clusters & \multicolumn{2}{|r|}{70} & \multicolumn{2}{|r|}{69} & \multicolumn{2}{|r|}{69} \\
\hline Prob $>$ F & \multicolumn{2}{|r|}{0.000} & \multicolumn{2}{|r|}{0.000} & \multicolumn{2}{|r|}{0.000} \\
\hline $\mathrm{R}^{2}$ adj. & \multicolumn{2}{|r|}{0.07} & \multicolumn{2}{|r|}{0.07} & \multicolumn{2}{|r|}{0.08} \\
\hline
\end{tabular}

Notes: (1) Least squares estimations; (2) standard errors are adjusted for clustering within regions per year; (3) ** is significant at the 99 percent level, * at the 95 percent level, and ${ }^{*}$ at the 90 percent level.

Source: Euro-Barometer Survey Series, 1970-1999, RAND-St. Andrews Chronology of International Terrorism, 1968-2000, provided by the Oklahoma City National Memorial Institute for the Prevention of Terrorism (www.mipt.org), Terror Attack Database of the International Institute for Counter-Terrorism (www.ict.org.il), Sutton (1994) and an updated version of the Sutton index provided by CAIN Web Service (www.cain.ulst.ac.uk). 
Table 2. Terrorism and life satisfaction in the United Kingdom and the Republic of Ireland; including macro variables

\begin{tabular}{|c|c|c|c|c|}
\hline \multirow{2}{*}{$\begin{array}{l}\text { Dependent Variable } \\
\text { Life satisfaction }\end{array}$} & \multicolumn{2}{|c|}{$\begin{array}{l}\text { United Kingdom } \\
1975-1998\end{array}$} & \multicolumn{2}{|c|}{$\begin{array}{l}\text { U.K. and Ireland } \\
\text { 1975-1998 }\end{array}$} \\
\hline & Coefficient & t-value & Coefficient & t-value \\
\hline \multicolumn{5}{|l|}{ Terrorism indicators } \\
\hline Number of incidents (in 10s) & $-0.059 * *$ & -2.89 & & \\
\hline Number of fatalities (in 100s) & & & $-0.093 * *$ & -4.25 \\
\hline \multicolumn{5}{|l|}{ Income } \\
\hline $\ln ($ income $)$ & $0.144 * *$ & 16.63 & $0.126 * *$ & 17.64 \\
\hline \multicolumn{5}{|l|}{ Macro Variables } \\
\hline GDP per capita (in $€ 1,000$ ) & $-0.028 * *$ & -2.08 & $0.019 * *$ & 2.11 \\
\hline Unemployed per capita & -0.995 & -0.77 & -0.028 & -0.03 \\
\hline Individual characteristics & \multicolumn{2}{|c|}{ Yes } & \multicolumn{2}{|c|}{ Yes } \\
\hline Year dummies & \multicolumn{2}{|l|}{ Yes } & \multicolumn{2}{|c|}{ Yes } \\
\hline Region dummies & \multicolumn{2}{|l|}{ Yes } & \multicolumn{2}{|c|}{ Yes } \\
\hline Constant & \multicolumn{2}{|c|}{ Yes } & \multicolumn{2}{|c|}{ Yes } \\
\hline Number of observations & \multicolumn{2}{|r|}{53,190} & \multicolumn{2}{|r|}{93,678} \\
\hline Number of clusters & \multicolumn{2}{|r|}{69} & \multicolumn{2}{|r|}{69} \\
\hline Prob $>$ F & \multicolumn{2}{|r|}{0.000} & \multicolumn{2}{|r|}{0.000} \\
\hline $\mathrm{R}^{2}$ adj. & \multicolumn{2}{|r|}{0.07} & \multicolumn{2}{|r|}{0.08} \\
\hline \multicolumn{5}{|c|}{$\begin{array}{l}\text { Notes: (1) Least squares estimations; (2) standard errors are adjusted for clustering within regions per } \\
\text { year; (3) } * * \text { is significant at the } 99 \text { percent level, } * \text { at the } 95 \text { percent level, and }{ }^{(*)} \text { at the } 90 \text { percent } \\
\text { level. }\end{array}$} \\
\hline \multicolumn{5}{|c|}{$\begin{array}{l}\text { Source: Euro-Barometer Survey Series, 1970-1999, Office for National Statistics, UK, OECD, Main } \\
\text { Economic Indicators, RAND-St. Andrews Chronology of International Terrorism, 1968-2000, } \\
\text { provided by the Oklahoma City National Memorial Institute for the Prevention of Terrorism } \\
\text { (www.mipt.org), Terror Attack Database of the International Institute for Counter-Terrorism } \\
\text { (www.ict.org.il), Sutton (1994) and an updated version of the Sutton index provided by CAIN Web } \\
\text { Service (www.cain.ulst.ac.uk). }\end{array}$} \\
\hline
\end{tabular}




\begin{tabular}{lrrr} 
& \multicolumn{1}{c}{ France } & United Kingdom & U.K. and Ireland \\
& $1973-1998$ & \multicolumn{1}{c}{$1975-1998$} & \multicolumn{1}{c}{$1975-1998$} \\
\hline Average annual household income & $€ 18,419$ & $€ 17,409$ & $€ 15,585$ \\
Reduction of terrorism & 11.33 incidents & 8.22 incidents & 87.78 fatalities \\
Compensating surplus $(C S)$ & $€ 2,521$ & $€ 5,587$ & $€ 6,375$ \\
$C S$ in percent of income & approx. 14\% & approx. 32\% & approx. 41\% \\
\hline
\end{tabular}

Notes: $C S$ is calculated for residents of Paris and London for a reduction in the number of incidents compared to the rest of France (except the region Provence-Alpes-Côte d'Azur) and the rest of Great Britain, and for the residents of Northern Ireland for a reduction in the number of fatalities compared to Great Britain and the Republic of Ireland.

Source: Own estimates on the basis of the coefficients depicted in table 1. 


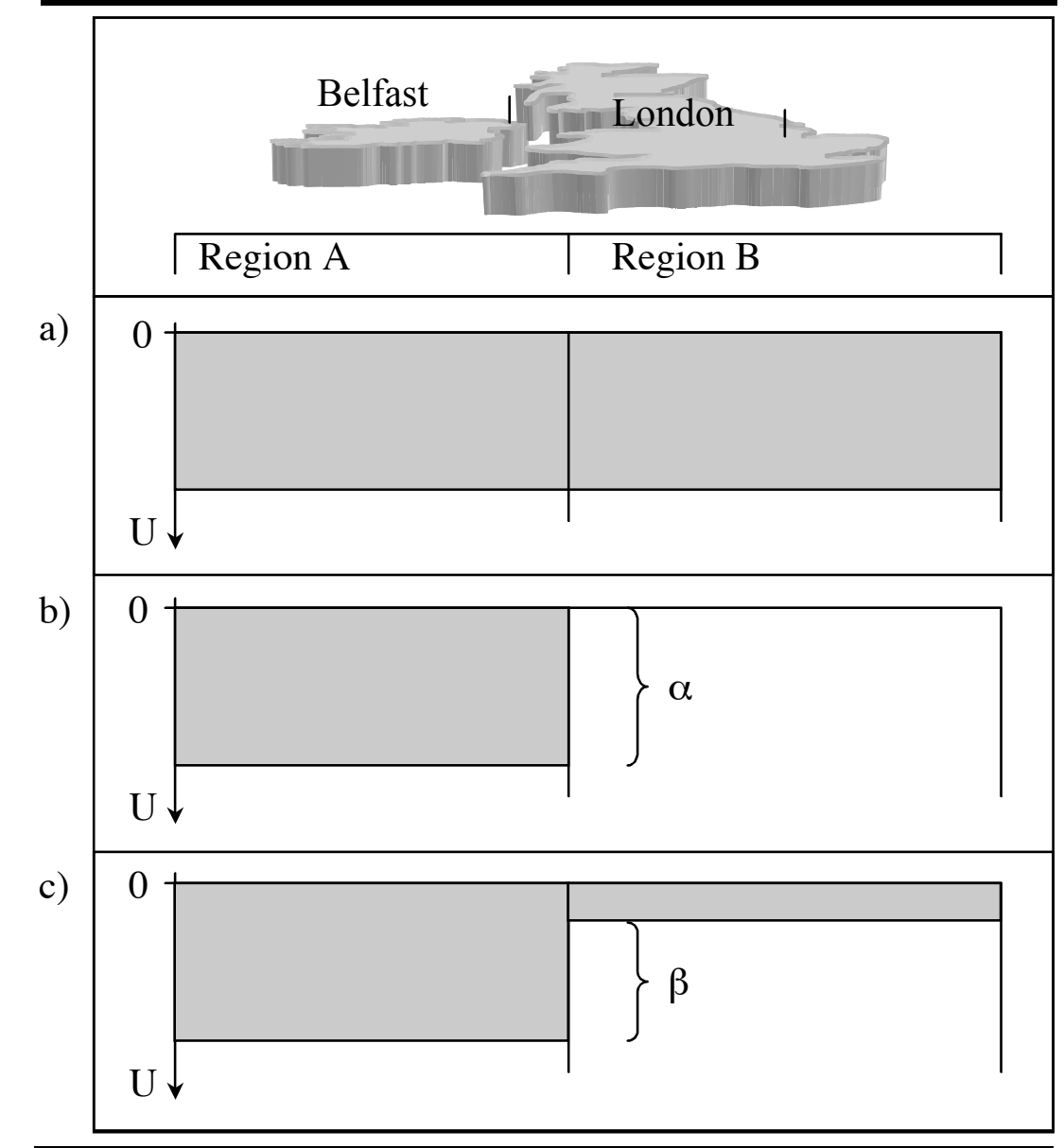

Notes: A negative externality in region A affects residents' subjective well-being a) equally in region $\mathrm{A}$ and region $\mathrm{B}, \mathrm{b}$ ) only in region $\mathrm{A}$ and $\mathrm{c}$ ) mainly in region $\mathrm{A}$ but with spillovers to region B. 
Figure 2: Number of incidents in France, 1973-1998, and the United Kingdom, 1975-1998

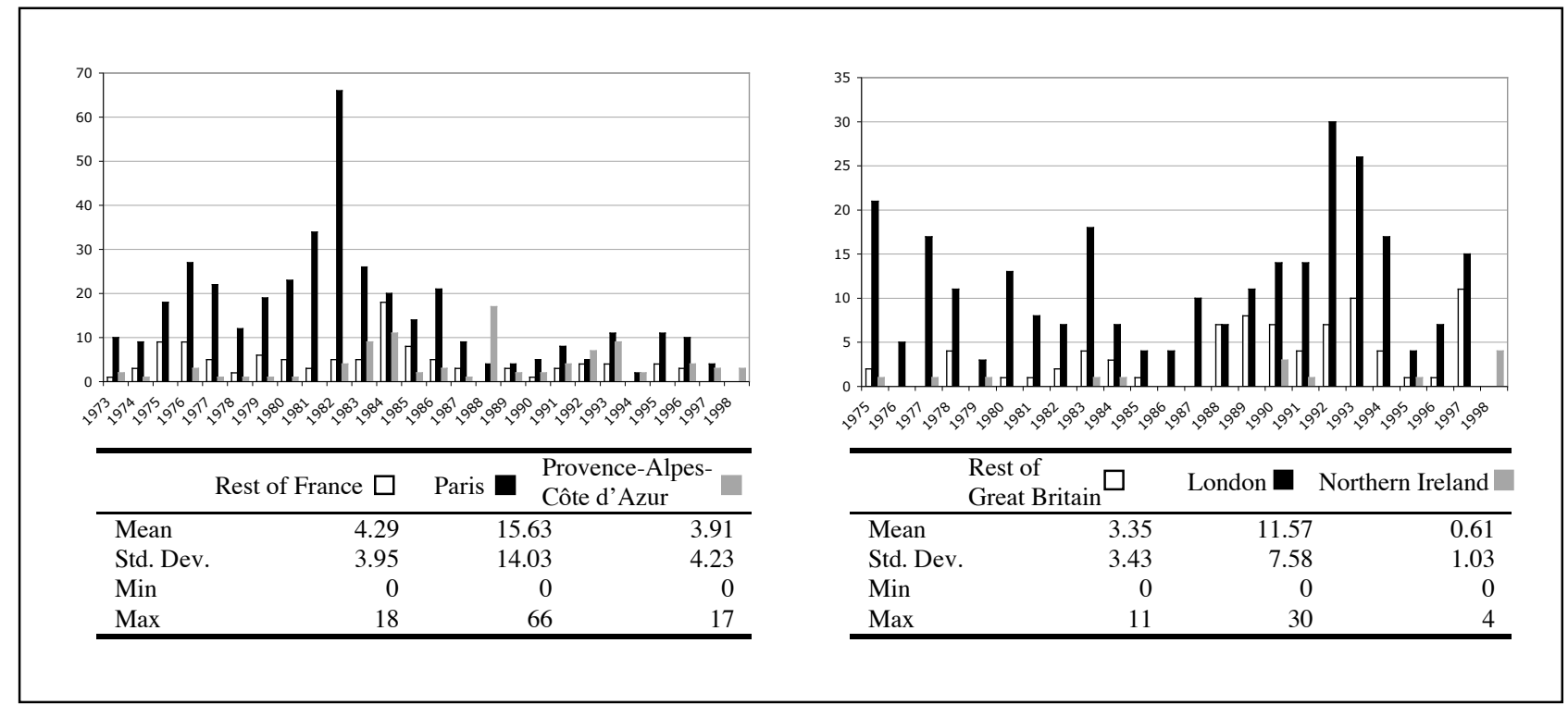

Figure 3: Number of victims of the Northern Ireland conflict, 1975-1998

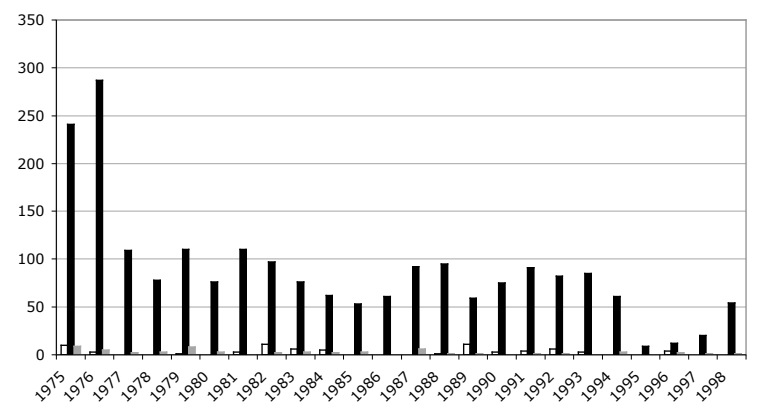

\begin{tabular}{lrrr}
\hline & Great Britain $\square$ & \multicolumn{2}{l}{$\begin{array}{l}\text { Northern } \\
\text { Ireland }\end{array}$} \\
& 2.91 & & \multicolumn{2}{l}{$\begin{array}{l}\text { Republic of } \\
\text { Ireland }\end{array}$} \\
\hline Mean & 3.68 & 90.57 & 2.67 \\
Std. Dev. & 0 & 60.77 & 2.79 \\
Min & 11 & 9 & 0 \\
Max & & 287 & 9 \\
\hline
\end{tabular}


Table A-1. Terrorism and life satisfaction in France, United Kingdom and Ireland; including control variables; part 1

\begin{tabular}{|c|c|c|c|c|c|c|}
\hline \multirow{3}{*}{$\begin{array}{l}\text { Dependent Variable } \\
\text { Life satisfaction }\end{array}$} & \multirow{2}{*}{\multicolumn{2}{|c|}{$\begin{array}{c}\text { France } \\
1973-1998\end{array}$}} & \multirow{2}{*}{\multicolumn{2}{|c|}{$\begin{array}{l}\text { United Kingdom } \\
\text { 1975-1998 }\end{array}$}} & \multirow{2}{*}{\multicolumn{2}{|c|}{$\begin{array}{l}\text { U.K. and Ireland } \\
\text { 1975-1998 }\end{array}$}} \\
\hline & & & & & & \\
\hline & Coefficient & t-value & Coefficient & t-value & Coefficient & $t$-value \\
\hline \multicolumn{7}{|l|}{ Terrorism indicators } \\
\hline Number of incidents (in 10s) & $-0.028 * *$ & -4.03 & $-0.068 * *$ & -3.25 & & \\
\hline Number of fatalities (in 100s) & & & & & $-0.077 * *$ & -4.00 \\
\hline \multicolumn{7}{|l|}{ Income (household) } \\
\hline $\ln ($ income $)$ & $0.218^{* *}$ & 17.22 & $0.144 * *$ & 16.66 & $0.128 * *$ & 17.42 \\
\hline Size of household ${ }^{1 / 2}$ & $-0.104 * *$ & -8.48 & $-0.077 * *$ & -5.72 & $-0.047 * *$ & -4.61 \\
\hline \multicolumn{7}{|l|}{ Individual characteristics } \\
\hline Male & \multicolumn{6}{|c|}{ Reference group } \\
\hline Female & $0.037 * *$ & 4.31 & $0.077 * *$ & 12.00 & $0.086^{* *}$ & 16.37 \\
\hline Age & $-0.021 * *$ & -11.13 & $-0.013 * *$ & -10.42 & $-0.013 * *$ & -13.09 \\
\hline $\mathrm{Age}^{2}$ & $0.000 * *$ & 12.37 & $0.000 * *$ & 12.61 & $0.000 * *$ & 15.88 \\
\hline Education, up to 15 years & \multicolumn{6}{|c|}{ Reference group } \\
\hline Education, 16-19 years & $0.077 * *$ & 7.20 & $0.068 * *$ & 7.56 & $0.103 * *$ & 12.54 \\
\hline Education, 20 years and more & $0.206^{* *}$ & 15.26 & $0.152 * *$ & 11.73 & $0.187 * *$ & 14.73 \\
\hline In education & $0.191 * *$ & 9.31 & $0.116^{* *}$ & 4.36 & $0.169 * *$ & 5.11 \\
\hline No children & \multicolumn{6}{|c|}{ Reference group } \\
\hline One child & -0.006 & -0.45 & -0.023 & -1.28 & -0.022 & -1.68 \\
\hline Two children & 0.023 & 1.33 & 0.000 & 0.02 & -0.014 & -0.90 \\
\hline Three children & 0.023 & 0.81 & -0.026 & -0.99 & -0.029 & -1.40 \\
\hline Four children and more & $-0.120 *$ & -2.29 & 0.036 & 1.44 & -0.003 & -0.11 \\
\hline
\end{tabular}


Table A-1. Terrorism and life satisfaction in France, United Kingdom and Ireland; part 2

\begin{tabular}{|c|c|c|c|c|c|c|}
\hline \multirow{3}{*}{$\begin{array}{l}\text { Dependent Variable } \\
\text { Life satisfaction }\end{array}$} & \multicolumn{2}{|c|}{ France } & \multirow{2}{*}{\multicolumn{2}{|c|}{$\begin{array}{l}\text { United Kingdom } \\
\text { 1975-1998 }\end{array}$}} & \multirow{2}{*}{\multicolumn{2}{|c|}{$\begin{array}{l}\text { U.K. and Ireland } \\
\text { 1975-1998 }\end{array}$}} \\
\hline & \multicolumn{2}{|c|}{ 1973-1998 } & & & & \\
\hline & Coefficient & t-value & Coefficient & t-value & Coefficient & $t$-value \\
\hline Single & \multicolumn{6}{|c|}{ Reference group } \\
\hline Married & $0.073 * *$ & 5.45 & $0.090 * *$ & 7.40 & $0.078 * *$ & 8.08 \\
\hline Living together & 0.004 & 0.28 & 0.019 & 0.88 & 0.009 & 0.41 \\
\hline Divorced & $-0.148 * *$ & -6.69 & $-0.255^{* *}$ & -12.68 & $-0.252 * *$ & -14.10 \\
\hline Separated & $-0.177 * *$ & -5.36 & $-0.262 * *$ & -8.48 & $-0.322 * *$ & -12.46 \\
\hline Widowed & $-0.085 * *$ & -4.31 & $-0.110 * *$ & -5.45 & $-0.104 * *$ & -7.38 \\
\hline Employed & \multicolumn{6}{|c|}{ Reference group } \\
\hline Unemployed & $-0.202 * *$ & -8.63 & $-0.374 * *$ & -20.16 & $-0.445 * *$ & 23.58 \\
\hline Retired & $0.165 * *$ & 9.50 & -0.022 & -1.64 & -0.014 & -1.20 \\
\hline Housewife & $0.060 * *$ & 4.72 & $-0.043 * *$ & -4.14 & $-0.045^{* *}$ & -5.60 \\
\hline Other occupation & $0.164 * *$ & 5.98 & $0.070 * *$ & 3.52 & 0.038 & 1.18 \\
\hline Living in a rural area & \multicolumn{6}{|c|}{ Reference group } \\
\hline Living in a small town & $-0.066^{* *}$ & -5.73 & $-0.048 * *$ & -4.29 & $-0.048 * *$ & -4.90 \\
\hline Living in a big town & $-0.089 * *$ & -7.86 & $-0.110 * *$ & -8.94 & $-0.120 * *$ & -11.47 \\
\hline Year dummies & \multicolumn{2}{|l|}{ Yes } & \multicolumn{2}{|c|}{ Yes } & \multicolumn{2}{|c|}{ Yes } \\
\hline Region dummies & \multicolumn{2}{|l|}{ Yes } & \multicolumn{2}{|c|}{ Yes } & \multicolumn{2}{|c|}{ Yes } \\
\hline Constant & $1.307 * *$ & 6.03 & $2.012 * *$ & 16.23 & $2.140 * *$ & 20.66 \\
\hline Number of observations & \multicolumn{2}{|c|}{43,231} & \multicolumn{2}{|r|}{53,190} & \multicolumn{2}{|r|}{93,678} \\
\hline Number of clusters & \multicolumn{2}{|r|}{70} & \multicolumn{2}{|r|}{69} & \multicolumn{2}{|r|}{69} \\
\hline Prob $>$ F & \multicolumn{2}{|r|}{0.000} & \multicolumn{2}{|r|}{0.000} & \multicolumn{2}{|r|}{0.000} \\
\hline $\mathrm{R}^{2}$ & \multicolumn{2}{|r|}{0.07} & \multicolumn{2}{|r|}{0.07} & \multicolumn{2}{|r|}{0.08} \\
\hline
\end{tabular}

Notes: (1) Least squares estimations; (2) standard errors are adjusted for clustering within regions per year; (3) $* *$ is significant at the 99 percent level, * at the 95 percent level, and ${ }^{*}$ at the 90 percent level. Results are not shown for dummies indicating that income, size of household, education, number of children, marital status, occupational status or size of community are not available.

Source: Euro-Barometer Survey Series, 1970-1999, RAND-St. Andrews Chronology of International Terrorism, 1968-2000, provided by the Oklahoma City National Memorial Institute for the Prevention of Terrorism (www.mipt.org), Terror Attack Database of the International Institute for Counter-Terrorism (www.ict.org.il), Sutton (1994) and an updated version of the Sutton index provided by CAIN Web Service (www.cain.ulst.ac.uk). 